\title{
The Study of English Teaching in Chinese and Foreign Cooperative Programs
}

\author{
Haiying $\mathrm{Ma}^{1, \mathrm{a}^{*}}$ and Rangjia Cai ${ }^{2, \mathrm{~b}}$ \\ ${ }^{1,2}$ School of Economics, Northwest Minzu University, Lanzhou (730124), P.R.China \\ alxmahaiying8888@163.com, b522766108 @qq.com
}

\begin{abstract}
Keywords: Higher education; Chinese-foreign cooperative program; English teaching
\end{abstract}
\begin{abstract}
Globalization has made the internationalization of institutions of higher learning inevitable, which has led to the Chinese and foreign cooperative school running program favored by the Chinese people. Undoubtedly, China's Sino foreign cooperative education program is mainly aimed at developed countries such as Britain and the United States. Therefore, Sino foreign cooperative education program require excellent English teaching as a prerequisite. Because English proficiency and International English test scores decide whether students can successfully finish their studies according to the requirements of Sino foreign cooperative education program, which is also the premise for the real implementation of Sino foreign cooperative education program. The traditional college English teaching model cannot effectively realize the purpose of Chinese and foreign cooperative school running program. Therefore, from the perspective of English teaching, it is helpful for us to further promote the development of Sino foreign cooperative education program and promote the training mode of internationalized talents.
\end{abstract}

\section{Introduction}

Globalization has made the internationalization of higher education inevitable. China's Chinese and foreign cooperative education in higher education is a prominent example of the internationalization of higher education in China. The Chinese and foreign cooperative program are favored by the Chinese people. The Chinese Chinese-foreign educational cooperation programs refer to the educational institutions organized by foreign educational institutions and Chinese educational institutions in China. At present, Chinese and foreign cooperation in running program generally refers to the cooperation of Chinese and foreign cooperation in higher education, vocational education and other fields encouraged by the state. Sino foreign cooperative education program are jointly established by Chinese universities with similar foreign universities. In essence, Chinese and foreign cooperation in running a school has a common feature, that is, it is attached to it.

In general, the form of education institutions in China is the first level college or the two level college. In the process of running a school in China and foreign countries, the foreign universities are the exporters of knowledge capital and cultural capital, and the Chinese side is the importer. Sino foreign cooperation in running program needs the introduction of China's urgent need for economic development, new disciplines and advanced educational concepts, teaching contents, training modes and management experience. In March 2013 the Ministry of Education issued the "Sino foreign cooperative education evaluation scheme", Sino foreign cooperative education institutions and programs of Bachelor degree or above, higher education evaluation, the key factors of the law school, the introduction of high quality educational resources, educational quality and social benefits of running stability and decided to evaluate the ability of sustainable development, the standard of Chinese and foreign cooperative education program behavior, points out the direction for future development. The cooperative education program in higher education mainly refers to the introduction of high-quality educational resources in foreign countries, and combines them with our educational resources. Through a series of teaching activities, we can improve the teaching level, scientific research and management ability of higher education in China. 
At present, China's Chinese and foreign cooperative running programs are usually used in the form of $2+2$ or $3+1$, that is to read 2 in China. Years or 3 years, and then abroad to read 2 years or 1 years, the two program signed agreement, mutual recognition of credit. The premise of such a student is to achieve the domestic academic achievement in the foreign cooperative school, and get the diploma and degree certificate from both sides after graduation.

\section{The Significance of English Teaching in Chinese and foreign Cooperative Programs}

There is no doubt that developed countries such as Britain and the United States are the main objects of China's foreign cooperation in running program. China's Sino foreign cooperative education program requires excellent English teaching as a prerequisite. Therefore, English teaching plays an important role in Chinese and foreign cooperation in running a school.

High quality English teaching is the prerequisite for the sustainable development of Chinese and foreign cooperative program. College students and their parents are eager to open up their students' vision and accept the cultivation of the two colleges and universities in China and the west, so as to make full preparation for the future. One of the prerequisites for achieving these is to be able to receive professional instruction from foreign universities to foreign teachers in China, and be able to pass examinations such as TOEFL or IELTS. The traditional college English teaching model can not effectively achieve the effect of English training in Chinese and foreign cooperative programs. Through the teaching of English, the problems and ways of implementation of Sino foreign cooperative education program will be enlightened, so as to promote the development of Sino foreign cooperative education programs and improve the training mode of internationalized talents in universities. Therefore, the English teaching quality is a prerequisite for sustainable development of Sino foreign cooperative education project, if students have a good foundation in English that cannot pass the relevant examinations, it would not acquire knowledge and skills from the cooperation project, Sino foreign cooperative education programs cannot go smoothly.

\section{The Difficulties Faced by English Teaching in Chinese and foreign Cooperative Program}

The goal of English Teaching in Chinese-foreign cooperative education program is to achieve The Test of English as a Foreign Language, TOE-FL or IELTS English International. TOEFL is a test held by the American education test service (ETS) to test the English level of non - native English speakers. Generally speaking, if a native English speaking student chooses to go to universities such as the United States and other English speaking countries, the official requirement is that they must pass the TOEFL test and reach the required grades of the school, so that they can be admitted. In addition, universities in Europe, Oceania and some other countries in Southeast Asia acknowledge the achievements of the TOEFL test. In terms of employment, United Nations agencies, multinational corporations, foreign enterprises and joint ventures will also take TOEFL scores when recruiting or recruiting civil servants in some countries. Japanese civil servants need to provide English TOEFL exam results. The contents of the TOEFL test usually involve the scene of the university campus and the living environment around it, and examine the students' four language skills, listening, speaking, reading and writing. IELTS is an English proficiency test system designed by the English examination department of the University of Cambridge examination committee to prepare for the study, work or settler in an English speaking country. Chinese and foreign cooperative program are mainly the main object of the national colleges and universities in English as the official language and the teaching language. Along with the steady development of Sino foreign cooperation in running program, the main link, English teaching, has also exposed some problems, some of which are outstanding, which puzzles the healthy development of Sino foreign cooperative education program. And the effective solution of these problems is imminent. Based on the practice of English Teaching for such program, taking the Sino foreign cooperative education program in ordinary universities as an example, this paper analyzes and explores the ways of English teaching and training and the way out of difficulties in Sino foreign cooperative education program. 
The low English Base. Generally speaking, the English scores of college students in Sino foreign cooperative education project in 80 basic points - 100 points (out of 150) in the range of 120, higher than the number of points are few. Obviously, the low English performance of the students is a prominent problem in the English Teaching of the cooperative program. The cost of the project is higher because of the higher cost of the project because of the teachers' teaching in the cooperative foreign program. Therefore, a lot of family economic conditions are relatively bad, but students with outstanding grades may not choose such program, so that the actual enrollment scores of such program are often not high. Generally speaking, the admission score of this type of project will be lower than that of the other majors in these programs. The level of English determines the performance and development of these students in this kind of project. Because most of the students' English level is not high, so in the later period of study, especially

It is difficult to adapt in the course of teaching foreign parties. In addition, the project requirements of the language is relatively high, so many program in teaching large increase in language courses, while the students English level is uneven, high school English learning effect based on College English learning is particularly high, resulting in many universities of Sino foreign cooperative education program failed to achieve good English teaching the teaching effect.

The Pool Student's English Foundation causes to English Professional Teaching Effect. Usually, according to the agreement signed by the two parties, the foreign universities will send teachers to Chinese colleges and universities in each school year.

Because of the cooperative education program student's English foundation is relatively weak; the majority of students can understand foreign language has not yet reached the level of teachers teaching full English, so will the Sino foreign cooperative education project to foreign teachers teaching the process of a series of problems. For example, students are absent from classes because they do not understand the lesson. In the classroom, they are distracted because they do not understand the lesson, and the questions are not positive. Homework cannot be submitted on time as required, all of which are puzzled and overwhelmed by the foreign teachers. It was hoped that the training of international talents could be realized, but the reality may make both the partners and the students disappointed in the actual situation of the project.

The IELTS or TOEFL Scores are not Qualified Leading to the Study Abroad. IELTS or TOEFL as an international common language test, from the four aspects of English listening, speaking, reading and writing, test students' language skills, which is used as a major index to measure whether students can go to English speaking countries. The content of IELTS and TOEFL test in foreign countries is different from that in our college English curriculum.

Because many colleges and universities have poor English, most students cannot pass the IELTS or TOEFL test, so that they cannot go to foreign cooperative colleges and universities. As a result, most of the students have to give up their intention to go abroad and choose to continue their studies at home, only to obtain a degree in domestic colleges and universities. This situation has seriously affected the development of Chinese and foreign cooperation in running program. If this situation continues, it will slowly deviate from the original intention of the project, so that the Chinese and foreign cooperative program will not continue to develop.

The Lack of Effective Organization Operation and Management. English teaching is a key link in Sino foreign cooperation in running program. There are still some unsatisfactory aspects in this link, which are mainly reflected in three aspects: weak teachers, inadequate curriculum and teaching materials. First of all, in the faculty, many hosted the Sino foreign cooperative education project in Colleges and universities to send in veteran soldiers and able captains teachers' selection is often not timely, strength slightly weak; secondly, the lack of students strengthen the purpose of the project, still follows the relevant course of the ordinary undergraduate students, and the future study abroad course of its curriculum convergence degree high, teachers often neglect to understand the necessity and importance of study abroad programs, so students cannot get in-depth understanding of cooperative education program and related information from future study teachers there; again, in the choice of materials of many contractors Sino foreign cooperative education project of Colleges and universities, still using the 
College English textbooks, and ignore the particularity of English Teaching in Sino foreign cooperative education project for students learning English, no later. Choose the teaching material for the IELTS (or TOEFL) test.

\section{The Path Choice of English Teaching}

Based on the above analysis, in order to achieve the goal of Sino foreign cooperation in running program and make sustainable development of Sino foreign cooperative education program, we need to make a series of reforms and adjustments for English Teaching in Sino foreign cooperative education program. In this reform and adjustment, starting from the actual situation of Sino foreign cooperation in running program, establishing the English teaching system suitable for Sino foreign cooperative education program is the key to solve the problem.

Controlling the Quality of the Source. From the actual situation of Sino foreign cooperation in running program, it is a great challenge for students to accept foreign teachers' English major lectures, which requires students to have corresponding English level. Therefore, the students who choose the project should be at least in the college entrance examination.

120 points (out of 150), that is to say, the totals meet the admission requirements, English scores the scores must be in control over the line. Only in this way can the course setting and teaching of Chinese and foreign cooperation programs are difficult to be effectively promoted after students' admission is avoided. Whether the quality of the source of students can be controlled depends on whether the relevant regulations of the college admissions department are scientific or not. At present, if the measures are appropriate, it will inevitably lead to the reduction of qualified sources, but can ensure the smooth teaching and higher teaching quality. If we do not improve the entry threshold, we will gradually form a high tuition fee in exchange for admission opportunities in practice, which is contrary to the purpose of Sino foreign cooperative education program.

Open Academic English and Special Purpose English courses. The academic English Course is to train the students how to learn and study in the process, a course to use English skills correctly, aiming to enable students to listen to lectures, take notes, academic discussion and academic presentations, academic reading and academic writing and other language skills of course. The success of China's Chinese and foreign cooperation in running a school is a model of academic English Teaching in the first year of the University. For example, speaking English in class for a particular topic is a kind of teaching method often used in foreign school classes. Through the academic English course, instruct the students to make a statement, grasp the link of the statement and the fixed expression of the relevant English that the links need to be used. Through the study of this course, students attend classes in China or go to foreign homes.

To Set up a Corresponding Training Course for TOEFL and IELTS. TOEFL and IELTS are generally recognized as a global language evaluation system. The results of the test are relatively comprehensive and fair, and the purpose of their setting is very clear. If the English Teaching in Sino foreign cooperative education project can get up close with the TOEFL and IELTS combination, not only can improve the quality of English teaching programs, but also conducive to China College English teaching and the international mainstream English teaching practice, so as to further accelerate the university English levels of tests and the internationalization of the TOEFL, IELTS and English test standards.

The Establishment of the Relevant Teaching Team. In the light of the current situation of College English Teaching in Colleges and universities in China, the special requirements of Chinese and foreign cooperative programs for English teaching are special. Therefore, English Teaching in Sino foreign cooperative education program in Colleges and universities should separately formulate corresponding policies from the aspects of curriculum setting, teaching material selection, and the selection of teaching staff, so as to ensure the continuous and smooth development of Sino foreign cooperative education program. 


\section{Conclusions}

In the background of global education internationalization, China the demand for international talents is increasing, and accordingly the study abroad is growing, the Sino foreign cooperative education project is one of the best ways, which leads to Chinese students to participate in the Sino foreign cooperation in running a number of substantial growths year after year. However, it is undeniable that the quality of English Teaching in Chinese colleges and universities seriously restricts the sustainable development of Chinese and foreign cooperative programs. In this regard, it should be reasonable choice of Sino foreign cooperative education project of students; secondly, set up in the curriculum, shall meet the requirements of Sino foreign cooperative education project of academic English course; thirdly, to carry out English Teaching in Sino foreign cooperative program meet the demand, and guide students to deep understanding of foreign advanced knowledge, technology and ideas, the training of students benefit from the Sino foreign cooperative education project, and realize the training goal of Sino foreign cooperative education program.

\section{Acknowledgements}

This work was supported by the Pilot project of comprehensive professional reform of International Economics and Trade (Joint Program, USU and NWUN) (Grant No:2017XJZYZHGGSD-01) and by Research project on education and teaching reform (Grant No:2017XJJG-12) of the Northwest Minzu University.

\section{References}

[1] Qin Meiqiong, Sino foreign cooperative education present situation analysis and Countermeasures of, the research of higher education, 2(2010)8-14.

[2] Cai Jigang, Demand analysis and teaching methods in academic English course, English teaching theory and practice, 1(2015)3-9.

[3] Cai Jigang, Liao Leizhao, academic English or professional English -- the reorientation of ESP teaching in Chinese universities, English teaching, 5(2010)5-11.

[4] Li Hong, The development of special purpose English and cooperative teaching of professional English, English teaching, 4 (2012)60-71.

[5] Lu Chuncheng, The thinking of Chinese and foreign cooperation in running a school in the perspective of globalization, Educational theory and practice, 2(2015)12-19.

[6] Zhang honghe, Research on the issue of educational property rights in China, Educational Exploration, 5(2010)5-11.

[7] Xia Jingtao, Study on the issue of educational sovereignty of Chinese and foreign cooperative education, Journal of Northeast Normal University (Philosophy Society Edition), 1 (2014) 30-37.

[8] Tang Zhentong, Education quality supervision mechanism of Sino foreign cooperative program, Educational Research, 2013, (12). 